\title{
Sex differences in cerebrovascular disease and other complex disease
}

\author{
Sandro Marini \\ Massachusetts General Hospital (MGH), Boston, USA
}

Sex is a biologic feature with a great impact on biology of many disease. Not only in the incidence of diseases, sex-related differences exist in outcomes of many conditions such as autoimmune diseases, heart failure, coronary artery disease, and ischemic stroke [1-3]. Compared to men, women with heart failure generally have a reduction of $36 \%$ in the probability of all-cause mortality [3]; women also present approximately a $1 / 3$ reduction of hazard ratio for one-year mortality after acute myocardial infarction [4] and slightly lower one-year mortality [5] after transient ischemic attack. Also, the pharmacology response is different among sexes. For instance, thrombolytic tissue plasminogen activator for ischemic stroke has a distinct sex-based efficacy [6]. The biology underlying observed sex differences has been harnessed to provide new insight into disease biology. For instance, the finding that women tend to have better traumatic brain injury outcomes than men [7] has led to the study of sex hormones to improve outcome after traumatic brain injury $[8,9]$.

Regarding cerebrovascular disease, most studies on gender differences have focused on ischemic stroke [10], demonstrating that women have greater 28 -day mortality after ischemic stroke $[11,12]$ and poorer functional outcome at discharge [13]. The few studies that have explored sex differences specifically in ICH (intracerebral haemorrhage) are characterized by discrepancies attributable to different choices of study setting (population-based or hospital-based), study population (Asian or Western), inclusion criteria, and duration of follow-up results or focus on functional outcomes [14-18]. As a result, whether sex influences outcome after ICH remains unclear [19]. Our group has demonstrated women with ICH experience a lower risk of both expansion and early and late mortality, even after controlling for known risk factors [20].

Differences between sex mortality may also involve complications. Overall $1 / 3$ of deaths can be attributed to post-stroke complications $[21,22]$. Common factors that influence outcome after cerebrovascular events include cardiological complications, venous thrombotic events (DVT), and infections [23]. Sex differences have been described for some of these outcomes, with pulmonary infections being particularly important [24].

The identification of patient populations at greatest risk for complications is the first step toward development of precision strategies to improve outcomes in the patient populations through prevention of complications. This is particularly important in diseases where therapeutics options are lacking.

Genetics is also well-suited to investigate the sex-specific architecture of common diseases and genetic-sex interaction has been widely explored $[25,26]$. In a recent review, 16 diseases and traits were associated with DNA polymorphisms with sex-dependent effects $[25,27]$. These studies highlight how genome predisposition to disease interacts with non-genetic factors that differ between males and females (such as sex hormones or anatomical differences) to initiate a response that eventually leads to the pathological trait. For instance, in cardiovascular disease, Genome Wide Association Study (GWAS) and sex-stratified approach has identified a metabolic pathway associated with coronary artery disease only in women [28] or with type II diabetes only in men [29].

Understanding the influence of biological sex in health and disease will give scientific bases to improve treatments with the rationale to eliminate the difference between the rate of complications among sexes.

\section{References}

1. Reeves MJ, Bushnell CD, Howard G, Gargano JW, Duncan PW, et al. (2009) Sex differences in stroke: epidemiology, clinical presentation, medical care, and outcomes. Lancet Naurol 7: 915-926. [Crossref]

2. Whitacre CC (2001) Sex differences in autoimmune disease. Nat Immunol 2: 777-780. [Crossref]

3. Simon T, Mary-Krause M, Funck-Brentano C, Jaillon P (2001) Sex differences in the prognosis of congestive heart failure: results from the Cardiac Insufficiency Bisoprolol Study (CIBIS II). Circulation 103: 375-380. [Crossref]

4. Mehilli J, Kastrati A, Dirschinger J, Pache J, Seyfarth M, et al. (2002) Sex-Based Analysis of Outcome in Patients With Acute Myocardial Infarction Treated Predominantly With Percutaneous Coronary Intervention. JAMA 287: 210-215. [Crossref]

5. Li OL, Silver FL, Lichtman J, Fang J, Stamplecoski M, et al. (2016) Sex differences in the presentation, care, and outcomes of transient ischemic attack: Results from the Ontario stroke registry. Stroke 47: 255-257. [Crossref]

6. Kent DM, Buchan AM, Hill MD (2008) The gender effect in stroke thrombolysis: of CASES, controls, and treatment-effect modification. Neurology 71: 1080-1083. [Crossref]

7. Berry C, Ley EJ, Tillou A, Cryer G, Margulies DR, et al. (2009) The effect of gender on patients with moderate to severe head injuries. J Trauma 67: 950-953. [Crossref]

8. Wright DW, Kellermann AL, Hertzberg VS, Clark PL, Frankel M, et al. (2007) ProTECT: A Randomized Clinical Trial of Progesterone for Acute Traumatic Brain Injury. Ann Emerg Med 49: 391-402. [Crossref]

9. Xiao G, Wei J, Yan W, Wang W, Lu Z (2008) Improved outcomes from the administration of progesterone for patients with acute severe traumatic brain injury: a randomized controlled trial. Crit care 12: R61. [Crossref]

10. Haast RA, Gustafson DR, Kiliaan AJ (2012) Sex differences in stroke. J Cereb Blood Flow Metab 32: 2100-2107. [Crossref]

11. Gall SL, Donnan G, Dewey HM, Macdonell R, Sturm J, et al. (2010) Sex Differences in Presentation, Severity, and Management of Stroke in a Population-Based Study. Neurology 75: 670-671. [Crossref]

*Correspondence to: Sandro Marini, Massachusetts General Hospital (MGH), Boston, USA, E-mail: SMARINI1@mgh.harvard.edu.

Received: April 16, 2018; Accepted: April 24, 2018; Published: April 27, 2018 
12. Appelros P, Stegmayr B, Terént A (2010) A review on sex differences in stroke treatment and outcome. Acta Neurol Scand 121: 359-369. [Crossref]

13. Lisabeth LD, Reeves MJ, Baek J, Skolarus LE, Brown DL, et al. (2015) Factors influencing sex differences in poststroke functional outcome. Stroke 46: 860-863. [Crossref]

14. Sheikh K, Bullock CM (2007) Effect of measurement on sex difference in stroke mortality. Stroke 38: 1085-1087. [Crossref]

15. Ganti L, Jain A, Yerragondu N, Jain M, Bellolio MF, et al. (2013) Female gender remains an independent risk factor for poor outcome after acute nontraumatic intracerebral hemorrhage. Neurol Res Int 2013: 219097. [Crossref]

16. Rodriguez-Luna D, Rubiera M, Ribo M, Coscojuela P, Piñeiro S, et al. (2011) Ultraearly hematoma growth predicts poor outcome after acute intracerebral hemorrhage. Neurology 77: 1599-1604. [Crossref]

17. van Asch CJ, Luitse MJ, Rinkel GJ, van der Tweel I, Algra A, et al. (2010) Incidence, case fatality, and functional outcome of intracerebral haemorrhage over time, according to age, sex, and ethnic origin: a systematic review and meta-analysis. Lancet Neurol 9: 167-176. [Crossref]

18. Roquer J, Rodríguez-Campello A, Jiménez-Conde J, Cuadrado-Godia E, GiraltSteinhauer E, et al. (2016) Sex-related differences in primary intracerebral hemorrhage. Neurology 87: 257-262. [Crossref]

19. Gokhale S, Caplan LR, James ML (2015) Sex differences in incidence, pathophysiology, and outcome of primary intracerebral hemorrhage. Stroke 46: 886-892. [Crossref]

20. Marini S, Morotti A, Ayres AM, Crawford K, Kourkoulis CE, et al. (2017) Sex differences in intracerebral hemorrhage expansion and mortality. J Neurol Sci 379: 112-116. [Crossref]
21. Koennecke HC, Belz W, Berfelde D, Endres M, Fitzek S, et al. (2011) Factors influencing in-hospital mortality and morbidity in patients treated on a stroke unit. Neurology 77: 965-972. [Crossref]

22. Rocco A, Pasquini M, Cecconi E, Sirimarco G, Ricciardi MC, et al. (2007) Monitoring after the acute stage of stroke: a prospective study. Stroke 38: 1225-1228. [Crossref]

23. Balami JS, Buchan AM (2012) Complications of intracerebral haemorrhage. Lancet Neurol 11: 101-118. [Crossref]

24. Marini S, Morotti A, Lena UK, Goldstein JN, Greenberg SM, et al. (2018) Men Experience Higher Risk of Pneumonia and Death After Intracerebral Hemorrhage. Neurocrit Care 28: 77-82. [Crossref]

25. Gilks WP, Abbott JK, Morrow EH (2014) Sex differences in disease genetics: evidence, evolution, and detection. Trends Genet 30: 453-463. [Crossref]

26. Liu LY, Schaub MA, Sirota M, Butte AJ (2012) Sex differences in disease risk from reported genome-wide association study findings. Hum Genet 131: 353-364. [Crossref]

27. Pan L, Ober C, Abney M (2007) Heritability Estimation of Sex-Specific Effects on Human Quantitative Traits. Genet Epidemiol 31: 338-347. [Crossref]

28. Hartiala JA, Tang WH, Wang Z, Crow AL, Stewart AF, et al. (2016) Genome-wide association study and targeted metabolomics identifies sex-specific association of CPS1 with coronary artery disease. Nat Commun 7:10558. [Crossref]

29. Morris AP, Voight BF, Teslovich TM, Ferreira T, Segrè AV, et al. (2012) Large-scale association analysis provides insights into the genetic architecture and pathophysiology of type 2 diabetes. Nat Genet 44: 981-990. [Crossref]

Copyright: @2018 Marini S. This is an open-access article distributed under the terms of the Creative Commons Attribution License, which permits unrestricted use, distribution, and reproduction in any medium, provided the original author and source are credited. 